\title{
Transcription factor decoy for activator protein-1 (AP-1) inhibits high glucose- and angiotensin II-induced type 1 plasminogen activator inhibitor (PAI-1) gene expression in cultured human vascular smooth muscle cells
}

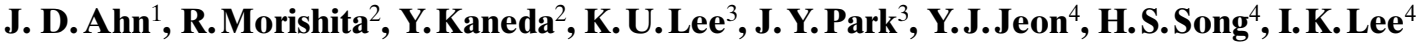 \\ ${ }^{1}$ Institute for Medical Science, Keimyung University School of Medicine, Taegu, Korea \\ ${ }^{2}$ Division of Gene Therapy Science, Graduate School of Medicine, Osaka University, Suita, Japan \\ ${ }^{3}$ Department of Internal Medicine, University of Ulsan School of Medicine, Seoul, Korea \\ ${ }^{4}$ Department of Internal Medicine, Keimyung University School of Medicine, Taegu, Korea
}

\section{Abstract}

Aims/hypothesis. Multiple factors, including hyperglycaemia and angiotensin II (Ang II), stimulate plasminogen activator inhibitor-1 (PAI-1) gene expression in human vascular smooth muscle cells. This study tested the hypothesis that hyperglycaemia and Ang II stimulate PAI-1 gene expression through activator protein-1 (AP-1) binding sites.

Methods. We evaluated the role of AP-1 in PAI-1 gene expression in human vascular smooth muscle cells under high D-glucose and Ang II stimulation using a double-stranded cis-element $A P-1$ oligodeoxynucleotide (decoy ODN).

Results. Activator protein 1 activity was stimulated by high glucose and Ang II treatment and the $A P-1$ decoy ODN, but not a mismatched decoy ODN, competed for AP-1 activity. The increase in PAI-1 expression by high glucose and Ang II was significantly at- tenuated by the $A P-1$ decoy ODN $(p<0.05$ or $p<0.01)$. The increase in $P A I-1$ expression by high glucose and Ang II action on AP-1 sites was also confirmed by promoter analysis of PAI-1. Activator protein 1 activation in response to either high glucose or co-stimulation with high glucose and Ang II was inhibited completely by calphostin C (a PKC inhibitor) and partially by genistein (a protein tyrosine kinase inhibitor).

Conclusion/interpretation. This study shows that high glucose and Ang II stimulate PAI-1 expression through AP-1 binding sites. Signal transduction after AP-1 activation by both high glucose and Ang II largely depends on PKC activation. These data indicate an important role for AP-1 in PAI-1 expression. [Diabetologia (2001) 44: 713-720]

Keywords Decoy ODN, glucose, diabetes, activator protein-1 (AP-1), plasminogen activator inhibitor-1.
The risk for cardiovascular disease is increased in patients with diabetes mellitus, especially when combined with hypertension [1-3]. One potential factor

Received: 27 November 2000 and in revised form: 22 January 2001

Corresponding author: I. K.Lee, M.D., PhD., Department of Internal Medicine, Keimyung University School of Medicine, 194 Dongsang-Dong, Joong-Ga, Taegu 700-712, Korea. e-mail: inkyulee@dsmc.or.kr

Abbreviations: AP-1, Activator protein 1; PAI-1, type 1 plasminogen activator inhibitor; HVSMC, human vascular smooth muscle cell; Ang II, angiotensin II; Decoy ODN, doublestranded oligodeoxynucleotide; Mis, mismatched decoy ODN; HG, high glucose; NG, normal glucose; HVJ, hemagglutinating virus of Japan. linking diabetes or hypertension to cardiovascular disease is an increased plasma concentration of plasminogen activator inhibitor-1 (PAI-1) [4-7]. PAI-1 is the main physiological inhibitor of the tissue-type plasminogen activator ( $\mathrm{t}-\mathrm{PA}$ ) and is considered to be the most important inhibitor of fibrinolysis [7]. Type 1 plasminogen activator inhibitor is produced in vascular endothelial and smooth muscle cells, in addition to hepatic cells $[8,9]$. High glucose and angiotensin II (Ang II), which are thought to play a major role in the pathogenesis of diabetes-associated and hypertension-associated atherosclerosis, stimulate $P A I-1$ gene expression in human vascular smooth muscle cells (VSMC) [10-11]. However, the cellular mechanism of increased $P A I-1$ expression in response to high glucose or Ang II has not yet been fully elucidated. Re- 
cent studies have indicated that high glucose and Ang II also activate activator protein-1 (AP-1), a key transcription factor, in a time-dependent and concentration-dependent manner [12-14]. The AP-1 complex, consisting of either a homodimer of Jun proteins or a heterodimer of Jun and Fos proteins, regulates the expression of various genes which mediate growth, inflammation and differentiation $[15,16]$. The promoter of the PAI-1 gene also contains four putative AP-1-like binding sites $[17,18]$.

We therefore hypothesized that high glucose and Ang II stimulate PAI-1 gene expression and production through the AP-1 binding sites in the PAI-1 promoter. To test this hypothesis, we used a new $A P-1$ decoy oligodeoxynucleotide (ODN) transfection approach. Transfection of cis-element double-stranded ODN as a decoy will result in the removal of all trans-factors from the endogenous cis-element of the same sequenced with a subsequent inhibition of gene expression [19-21]. We examined whether the high glucose-induced or Ang II-induced increase in $P A I-1$ gene expression in human VSMC is abolished by transfection of a cis-element $A P-1$ decoy ODN.

\section{Materials and methods}

Cell culture. Human VSMC were harvested from minced pieces of human distal mammary arteries, which were obtained during coronary artery bypass surgery at Dongsan Medical center (Taegu, Korea). The VSMC were cultured in Dulbecco's modified Eagle's medium (DMEM, Gibco, Grand Island, N. Y., USA) containing $20 \%$ fetal bovine serum (Gibco). The purity of VSMC was characterized by positive staining with smooth muscle-specific $\alpha$-actin monoclonal antibodies (Sigma-Aldrich, St. Louis, Mo., USA).

After reaching 80 to $90 \%$ confluence in $100-\mathrm{mm}$ dishes, human VSMC were serum starved for $24 \mathrm{~h}$ in serum-free medium and were subjected to either a control normal glucose medium (DMEM containing $2 \%$ serum and $5.5 \mathrm{mmol} / \mathrm{l} \mathrm{D-glu-}$ cose) or a high glucose medium (DMEM containing $2 \%$ serum and $22 \mathrm{mmol} / \mathrm{l} \mathrm{D}$-glucose). To examine the effect of Ang II, $100 \mathrm{nmol} / \mathrm{l}$ Ang II was added to the medium and incubated for various time periods. Cells then were processed for nuclear protein extraction or RNA extraction as described below.

Isolation of PAI-1*cDNA probe by reverse transcription $(R T)$ $P C R$. A cDNA probe for human PAI-1 was generated by RTPCR of RNA from VSMC using the oligonucleotide primers ATAGAATTCCACGAGTACGACATCCTGGAACTGC, and ATAGGATCCCCCTCTGAGGTCCACTTCAGTCTCC to the human PAI-1 coding sequence. Reverse transcription was done on $0.2 \mu \mathrm{g}$ RNA in the presence of $1 \mathrm{mmol} / \mathrm{l}$ antisense primer, $20 \mathrm{mmol} / 1 \mathrm{NTP}, 10 \mathrm{mmol} / \mathrm{l}$ dithiothreitol, $50 \mathrm{mmol} / \mathrm{l} \mathrm{TRIS}$, $\mathrm{pH} 8.3,75 \mathrm{mmol} / \mathrm{K} \mathrm{KCl}, 3 \mathrm{mmol} / 1 \mathrm{MgCl}_{2}$, and $10 \mathrm{U}$ of RTase for $1 \mathrm{~h}$ at $37^{\circ} \mathrm{C}$. The PCR reaction mixture included $1.0 \mathrm{mmol} / \mathrm{l}$ of the primers, $10 \% \mathrm{RT} \operatorname{mix}, 10 \mathrm{mmol} / \mathrm{l}$ TRIS, $\mathrm{pH} 8.3,50 \mathrm{mmol} / 1 \mathrm{KCl}, 3 \mathrm{mmol} / 1 \mathrm{MgCl}_{2}, 0.001 \%$ gelatin, $2.0 \mathrm{mmol} / \mathrm{l} \mathrm{NTP}$ and $0.05 \mathrm{U} / \mu \mathrm{l}$ Amplitaq (Perkin-Elmer Cetus, Norwalk, Conn., USA). The PCR conditions were $94^{\circ} \mathrm{C} \cdot 30 \mathrm{~s}, 59^{\circ} \mathrm{C} \cdot 2 \mathrm{~min}, 72^{\circ} \mathrm{C} \cdot 30 \mathrm{~s}$, for 40 cycles. The agarose gel-purified PCR product was cloned into pBluescript KS
(Stratagene Inc., La Jolla, Calif., USA) using the EcoRI or BamHI restriction sequences that were included in the 5' ends of the primers [10].

Northern blot analysis. The radiolabelled probes used for northern blot analysis were prepared by random primer labelling with $\left[\alpha-{ }^{32} \mathrm{P}\right] \mathrm{dCTP}$ using a random primer labelling kit (Amersham, Arlington Heights, Ill., USA). After the labelling reaction, the radiolabelled probes were purified on a NAP-5 column (Pharmacia, Uppsala, Sweden). Total RNA for northern analysis was extracted by RNeasy RNA extraction kit (Qiagen, Hilden, Germany). Ten micrograms of total RNA was applied to a $1 \%$ formaldehyde-agarose gel and transferred to a nylon membrane. The nylon membrane was hybridized in Express Hyb solution at $65^{\circ} \mathrm{C}$ for $2 \mathrm{~h}$ with a radiolabelled cDNA probe and washed according to the manufacturer's instructions. The membrane was exposed to X-ray film for 24 to $48 \mathrm{~h}$, and the mRNA expression was quantified with densitometric analysis. Loading differences were normalized using an 18 s rRNA cDNA probe.

Measurement of secreted PAI-1 protein. To measure the secreted PAI-1 protein from cultured cells, conditioned medium was collected, centrifuged at $600 \mathrm{~g}$ for $10 \mathrm{~min}$ and stored at $-20^{\circ} \mathrm{C}$. Immunoassay for PAI-1 was carried out using an enzyme immunoassay kit (Biopool, Umea, Sweden).

Preparation of decoy $O D N$. The sequences of the phosphorothioate double-stranded ODN against the AP-1 binding site and the mismatched ODN used in this study were prepared as previously reported [20]: $A P-1$ decoy ODN (consensus sequences are underlined), 5'-AGCTTGTGAGTCAGAAGCT-3', 3'-TCGAACACTCAGTCTTCGA $\overline{A-5 ' ; ~ m i s m a t c h e d ~}$ decoy ODN, 5'-AGCTTGAATCTCAGAAGCT-3', 3'TCGAACTTAGAGTCTTCGA-5'. The ODNs were annealed for $2 \mathrm{~h}$, while the temperature descended from $80^{\circ} \mathrm{C}$ to $25^{\circ} \mathrm{C}$.

Electrophoretic mobility shift assay (EMSA). Nuclear extracts were prepared from VSMC as described previously, with minor modifications [22]. Briefly, 80 to $90 \%$ confluent VSMC growing in 100-mm dishes in normal or high glucose growth medium were washed twice with cold PBS and collected. The cells were homogenized in $400 \mu$ l of ice-cold buffer A $(10 \mathrm{mmol} / \mathrm{l}$ HEPES, $10 \mathrm{mmol} / 1 \mathrm{KCl}, 0.1 \mathrm{mmol} / \mathrm{l}$ EDTA, $1 \mathrm{mmol} / \mathrm{l}$ DTT, $0.5 \mathrm{mmol} / \mathrm{l} \mathrm{PMSF}, 10 \mu \mathrm{g} / \mu \mathrm{l}$ aprotinin and $10 \mu \mathrm{g} / \mu \mathrm{l}$ leupeptin) and incubated in ice for $15 \mathrm{~min}$. After $25 \mu \mathrm{l}$ of NP-40 treatment, the homogenate was laid on buffer B $(20 \mathrm{mmol} / 1 \mathrm{HEPES}, 0.4 \mathrm{~mol} / \mathrm{l} \mathrm{NaCl}, 1 \mathrm{mmol} / \mathrm{l}$ EDTA, $1 \mathrm{mmol} / \mathrm{l} \mathrm{DTT}$ and $1 \mathrm{mmol} / \mathrm{l} \mathrm{PMSF}$ ), and centrifuged at $12,000 \mathrm{~g}$ for $10 \mathrm{~min}$. After centrifugation, the supernatant was collected as nuclear extracts and the amount of nuclear protein was measured with a protein assay kit (Bio-Rad, Richmond, Calif., USA). The DNA probes such as those for the $A P-1$ and mismatched decoy ODNs were labelled as primers using $\left[\gamma_{-}{ }^{32} \mathrm{P}\right] \mathrm{ATP}$ and T4 polynucleotide kinase. After end labelling, ${ }^{32} \mathrm{P}$-labelled ODN were purified on a NAP-5 column. The protein-DNA binding reaction was done at room temperature for $20 \mathrm{~min}$ in a volume of $20 \mu \mathrm{l}$. The reaction mixture contained $6 \mu \mathrm{g}$ of nuclear extract, $100 \mu \mathrm{g} / \mathrm{ml}$ poly dI:dC, $10 \mathrm{mmol} / \mathrm{l}$ TRIS/HCl (pH 7.5), $50 \mathrm{mmol} / \mathrm{l} \mathrm{NaCl}, \quad 0.5 \mathrm{mmol} / \mathrm{l}$ EDTA, $0.5 \mathrm{mmol} / \mathrm{l}$ DTT, $1 \mathrm{mmol} / \mathrm{l} \mathrm{MgCl}_{2}, 4 \%$ glycerol and $60000 \mathrm{cpm}{ }^{32} \mathrm{P}$-labelled primer DNA. After incubation, the samples were loaded onto $4 \%$ native polyacrylamide gels in $0.5 \cdot$ TRIS-borateEDTA buffer and were run at $150 \mathrm{~V}$ for $2 \mathrm{~h}$. The gels were dried and visualized by autoradiography. For competition 
studies, the experimental conditions were identical, except that the appropriate competitor ODN was added to the reaction mixture at 50 -fold to 100 -fold molar excess before the nuclear extract was added.

Preparation of hemagglutinating virus of Japan (HVJ)-liposomes. The HVJ-AVE liposomes were prepared as described previously [23]. Briefly, cholesterol, dioleoylphosphatidylethanolamine (DOPE), phosphatidylcholine (ePC), sphingomyeline (eSph) and phosphatidylserine (bPS) were mixed in a molar ratio of 50:13.3:13.3:13.3:10. The lipid mixture was deposited on the sides of a flask by removal of chloroform. The dried lipid was hydrated in $200 \mu \mathrm{l}$ balanced salt solution (BSS; $137 \mathrm{mmol} / \mathrm{l} \mathrm{NaCl}, 5.4 \mathrm{mmol} / \mathrm{l} \mathrm{KCl}, 10 \mathrm{mmol} / \mathrm{l}$ TRIS-HCl, $\mathrm{pH}$ 7.6) containing the ODN. Liposomes were prepared by shaking and filtration. Purified HVJ ( $Z$ strain) was inactivated by UV irradiation for $3 \mathrm{~min}$ just before use. The liposome suspension was mixed with HVJ in a total volume of $2 \mathrm{ml} \mathrm{BSS}$. The mixture was incubated at $4^{\circ} \mathrm{C}$ for $5 \mathrm{~min}$ and then for $30 \mathrm{~min}$ with gentle shaking at $37^{\circ} \mathrm{C}$. Free HVJ was removed from the HVJ-liposomes by sucrose density gradient centrifugation. The top layer of the sucrose gradient was collected for use.

Transfection of FITC-labelled ODNs into VSMC. Cells were grown in 2 chamber slides to $80 \%$ confluence. Firstly, $200 \mu \mathrm{l}$ of HVJ-liposome complex with FITC-labelled $A P-1$ decoy ODN was incubated for $5 \mathrm{~min}$ at $4{ }^{\circ} \mathrm{C}$ and for $30 \mathrm{~min}$ at $37^{\circ} \mathrm{C}$. Secondly, LipofectAMINE (Life Technologies, Rockville, Md., USA): FITC-labelled $A P-1$ decoy ODN (300 nmol/l) was added to the wells dropwise, after the mixture of LipofectAMINE, according to the manufacturer's directions. The cells were incubated for $35 \mathrm{~min}$ at $37^{\circ} \mathrm{C}$. Then, after changing to fresh medium with $5 \%$ calf serum, the cells were incubated in a $\mathrm{CO}_{2}$ incubator. Cells were fixed with $3 \%$ paraformaldehyde at 1,2 or 3 days after transfection. After mounting, the cells were examined by fluorescent microscopy.

Luciferase assay. The PAI-1 luciferase construct was kindly provided by Dr. Rifkin (New York University, N.Y., USA) [24]. Plasmids and decoy ODN were co-transfected into human VSMC by the HVJ-liposome method. On the day before transfection, $2 \cdot 10^{5}$ cells were inoculated into each six-well plate. Then, $200 \mu \mathrm{l}$ of the HVJ-liposome complex was added directly into each plate without removing any medium. The pSV- $\beta$-gal (Promega, Madison, Wis., USA) was co-transfected with the test plasmid to monitor the transfection efficiency. At $48 \mathrm{~h}$ after transfection, cells were harvested to examine the luciferase expression. The cells were washed twice with PBS and were suspended in $250 \mu \mathrm{l}$ of $1 \mathrm{X}$ Cell Culture Lysis Reagent (Promega, USA). The lysates were examined for $\beta$-galactosidase and luciferase activity.

Statistical analysis. Results are expressed as means \pm SEM. Analysis of variance with a subsequent Duncan's test was used to determine the significance of differences in multiple comparisons. A $p$ value of less than 0.05 was considered statistically significant. All experiments were carried out at least three times.

\section{Results}

Effect of high glucose and Ang II on AP-1 activation and PAI-1* expression. We initially examined whether treatment with Ang II leads to a statistically significant increase in the DNA binding activity of the
A)
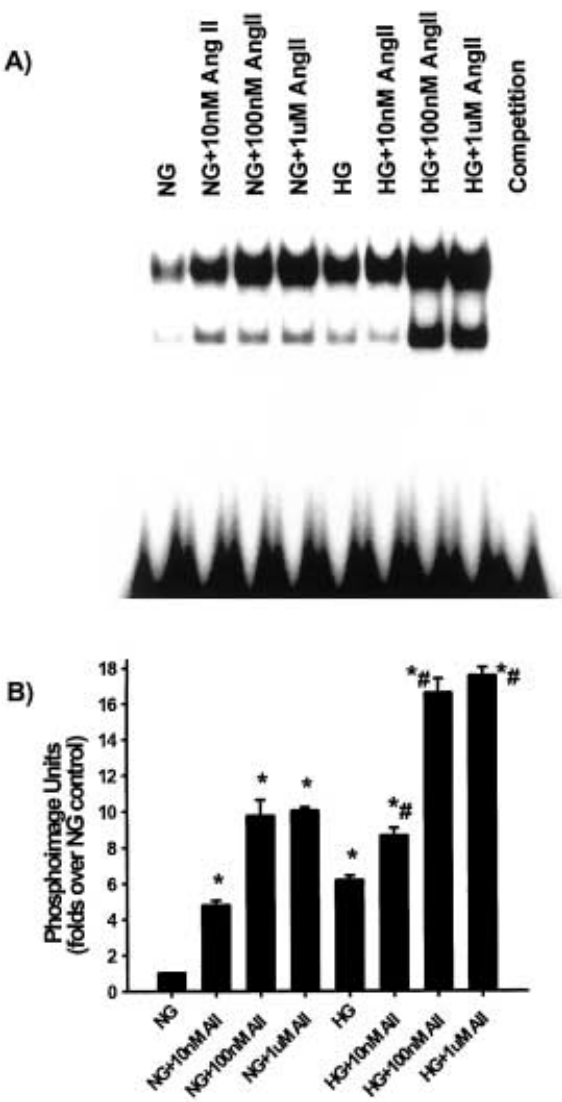

Fig. 1A, B. AP-1 DNA binding activity in human VSMC as assessed by a gel mobility shift assay. A Typical example of a gel shift assay. This experiment was repeated three times (NG, VSMC cultured with normal glucose; HG, VSMC cultured with high glucose, Competition, cold $A P-1$ probe). B Effect of high glucose or Ang II on AP-1 activity. Quantification of EMSA results expressed as the means \pm SEM of three independent experiments. $* p<0.01$ compared to $\mathrm{NG}$, and $\# p<0.01$ compared to $\mathrm{HG}$

transcription factor AP-1 under normal and high glucose conditions. As expected, culturing in high glucose significantly increased AP-1 binding activity (by approximately $600 \%$ ) as compared to culturing in normal glucose (Fig. 1, $p<0.01$ ). Similarly, Ang II also increased AP-1 DNA binding activity in a dosedependent manner, both in the cells cultured at normal glucose concentration and in the cells cultured at high glucose (Fig. 1A, $p<0.01$ ). We also examined the effect of Ang II on PAI-1 gene expression under normal or high glucose conditions. The high glucose condition significantly increased PAI-1 mRNA expression as compared to the normal glucose condition (Fig. $2, p<0.01$ ). Of note, the addition of Ang II to cells cultured with high glucose showed an additive effect of Ang II and high glucose on PAI-1 mRNA expression in a dose-dependent manner (Fig. 2A and $\mathrm{B}, p<0.01)$. Consistent with the mRNA expression, high glucose as well as Ang II increased the concentration of PAI-1 protein in the conditioned culture media (Fig. 2C, $p<0.01$ ). 


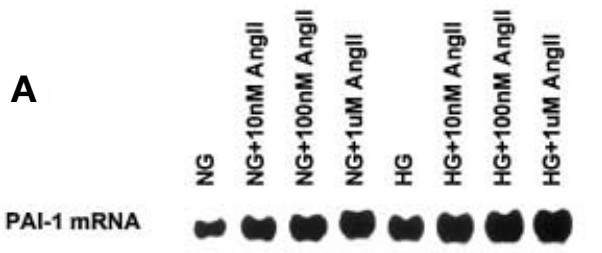

18S rRNA 9000
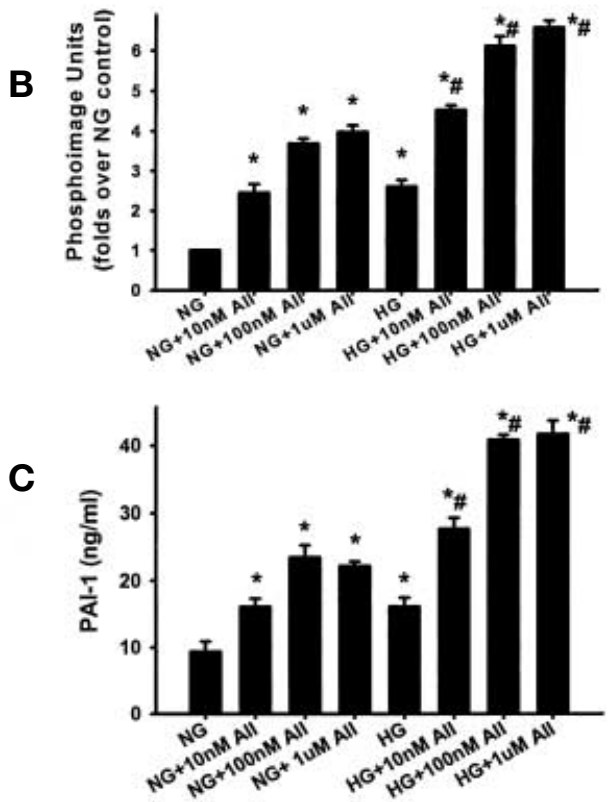

Fig. 2 A-C. Effect of high glucose or AngII on activation of the $P A I-I$ gene in human VSMC. A Typical northern blotting analysis for $P A I-I$ (NG, VSMC cultured with normal glucose; HG, VSMC cultured with high glucose; Competition, cold $A P-I$ probe). B Effect of high glucose or AngII on PAI-I mRNA in human VSMC. Results are the means \pm SEM of five independent experiments. ${ }^{*} p<0.01$ compared to $\mathrm{NG}$, and $\# p<0.01$ compared to HG. C Effect of high glucose or Ang II on PAI-1 concentration in the conditioned medium of human VSMC as assessed by ELISA. Values are means \pm SEM of five independent experiments. ${ }^{*} p<0.01$ compared to $\mathrm{NG}$, and $\# p<0.01$ compared to $\mathrm{HG}$

Effect of the AP-1* decoy ODN on PAI-1* expression under high glucose conditions or Ang II stimulation. Given the finding that AP-1 and PAI-1 expression seem to be co-organized under the Ang II or high glucose conditions, we reasoned that Ang II might stimulate $P A I-1$ gene expression through the AP-1 complex. To prove this hypothesis, we transfected the $A P-1$ decoy ODN (100 nmol/l or $300 \mathrm{nmol} / \mathrm{l})$ into VSMC stimulated with Ang II using the HVJ-liposome method. We first compared the efficiency of transfecting the $A P-1$ decoy ODN into human VSMC using this method versus LipofectAMINE. Transfection of a fluorescent (FITC)-labelled $A P-1$ decoy ODN using the HVJ-liposome method resulted in strong fluorescence (Fig. 3), readily detected in nuclei even at $72 \mathrm{~h}$ after transfection. In contrast, after 35 min exposure to FITC-labelled $A P-1$ ODN in

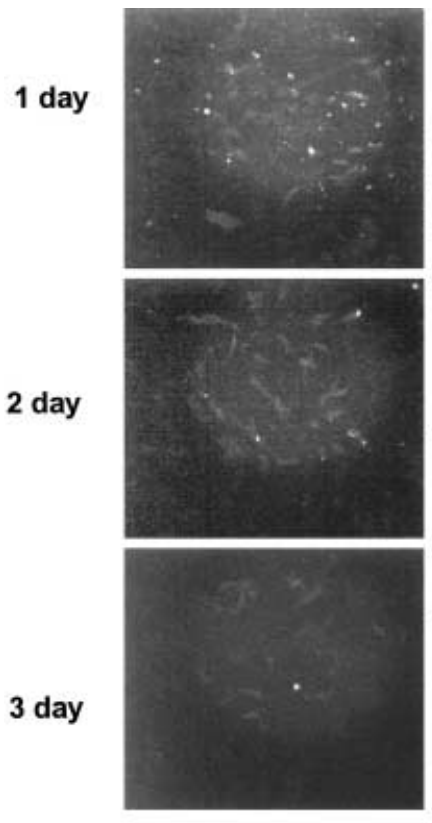

LipofectAmin
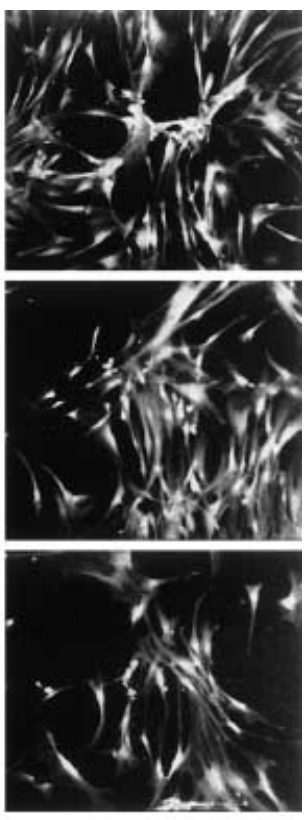

HVJ-liposome
Fig.3. Fluorescent microscopy of human VSMC after transfection of FITC-labelled $A P-1$ decoy ODN using either the HVJ-liposome method or LipofectAMINE. Representative photographs $(\times 100)$ of the distribution of FITC-labelled ODN from four different experiments. 1, 2, 3 day $=1,2$ or 3 days after transfection

solution (300 nmol/l) using LipofectAMINE, only weak fluorescence could be observed. Thus, we chose to use the HVJ-liposome method to transfect the $A P-1$ decoy ODN into human VSMC for the remainder of the experiments. Transfection of the $A P-1$ decoy ODN by the HVJ-liposome method significantly attenuated the AP-1 activity induced by high glucose, in a dose-dependent manner (Fig. 4). In addition, the increase in AP-1 activity induced by Ang II was also inhibited by the $A P-1$ decoy ODN as compared to a mismatched decoy ODN $(p<0.01)$.

We further investigated the effect of the $A P-1$ decoy ODN treatment on PAI-1 gene expression. According to the decrease in AP-1 activity, transfection of the AP-1 decoy ODN inhibited the PAI-1 gene expression induced by either the high glucose condition $(p<0.05)$ or by Ang II $(p<0.01)$, whereas the mismatched decoy ODN did not alter PAI-1 expression (Fig. 5A, B). The PAI-1 protein concentrations were also decreased by the transfection of the $A P-1$ decoy ODN (Fig. 5 C, $p<0.05$ or $p<0.01$ ). To further confirm the regulation of $P A I-1$ expression through the AP-1 complex, we co-transfected a PAI-1 luciferase construct and an $A P-1$ decoy ODN into human VSMC and treated them with either high glucose or Ang II. Treatment with high glucose increased PAI-1 promoter activity as compared to the normal glucose condition (Fig. 6, $p<0.01$ ). As expected, the increase 
A
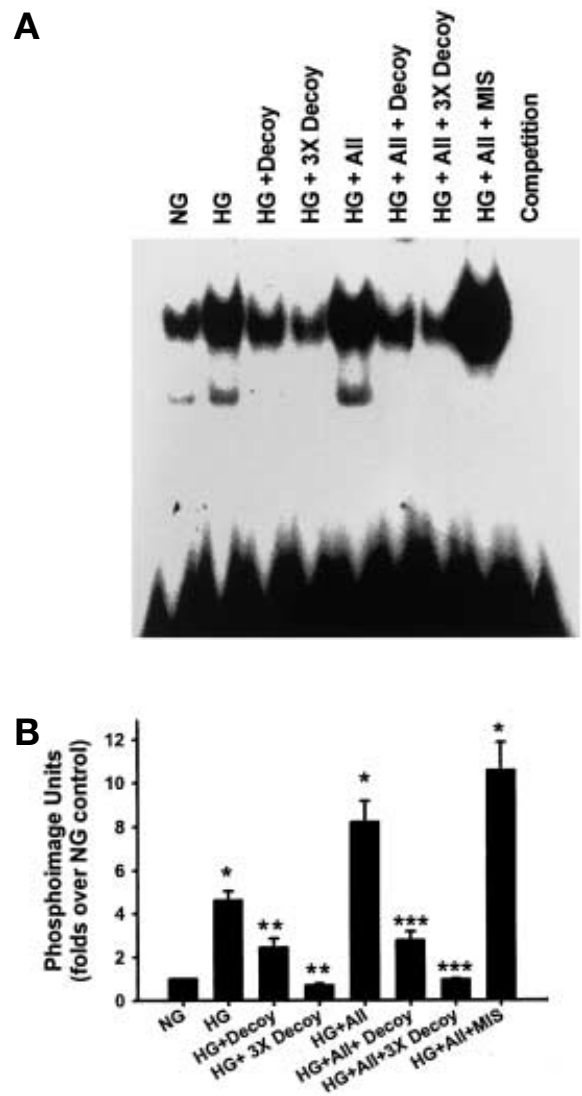

Fig. 4A, B. Effect of the $A P-1$ decoy ODN on AP-1 DNA binding activity in human VSMC. A Typical example of a gel shift assay from VSMC transfected with the AP-1 decoy ODN. This experiment was repeated three times (NG, VSMC cultured with normal glucose; HG, VSMC cultured with high glucose; Decoy, VSMC transfected with $100 \mathrm{nmol} / \mathrm{l}$ or 300 nmol/l $(\times 3) A P-1$ decoy ODN; MIS, VSMC transfected with a mismatched decoy ODN; cold AP-1, cold $A P-1$ probe). B Effect of $A P-1$ decoy ODN on AP-1 activity induced by high glucose or Ang II. Quantification of EMSA results expressed as the means \pm SEM of three independent experiments. $* p<0.01$ compared to NG, $* * p<0.05, * * * p<0.01$ vs HG or $\mathrm{HG}+$ Ang II

in luciferase activity seen with high glucose was decreased by the $A P-1$ decoy ODN in a dose-dependent manner $(p<0.01)$. Similarly, the $A P-1$ decoy ODN, but not the mismatched decoy ODN, abolished the increase in luciferase activity stimulated by co-treatment with high glucose and Ang II $(p<0.01)$. These data clearly show that high glucose and Ang II stimulate PAI-1 expression through AP-1.

Effect of a PKC and tyrosine kinase inhibitor on AP-1 activity. To clarify the signal transduction pathway upstream of AP-1 activation by high glucose or Ang II, cells were treated with a specific PKC inhibitor, calphostin $\mathrm{C}(100 \mathrm{nmol} / \mathrm{l})$, or a tyrosine kinase inhibitor, genistein $(1 \mu \mathrm{mol} / \mathrm{l})$. Calphostin $\mathrm{C}$ completely blocked the activation of AP-1 activity induced by either high glucose or co-stimulation of high glucose
A

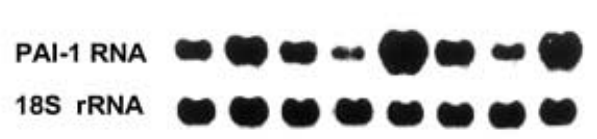

B

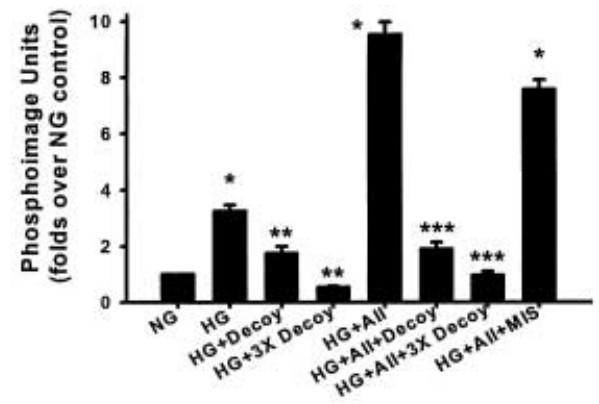

C

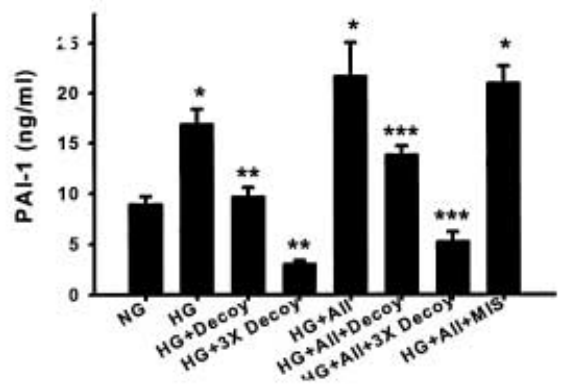

Fig.5 A-C. Effect of the $A P-1$ decoy ODN on activation of $P A I-1$ gene in human VSMC (NG, VSMC cultured with normal glucose; HG, VSMC cultured with high glucose; Decoy, VSMC transfected with $100 \mathrm{nmol} / \mathrm{l}$ or $300 \mathrm{nmol} / 1(\times 3) A P-1$ decoy ODN; MIS, VSMC transfected with a mismatched decoy ODN). A Typical northern blotting analysis for PAI-1. B Effect of the AP-1 decoy ODN on PAI-1 mRNA induced by high glucose or Ang II in human VSMC. Results are the means \pm SEM of five independent experiments. ${ }^{*} p<0.01$ compared to $\mathrm{NG}, * * p<0.05, * * * p<0.01$ vs $\mathrm{HG}$ or $\mathrm{HG}+$ Ang II. C Effect of the $A P-1$ decoy ODN on PAI-1 concentration in the conditioned medium of human VSMC as assessed by ELISA. Values are means \pm SEM of four independent experiments. $* p<0.01$ compared to NG, ${ }^{* *} p<0.05, * * * p<0.01$ vs $\mathrm{HG}$ or $\mathrm{HG}+$ Ang II

and Ang II (Fig. 7, $p<0.01$ ). On the other hand, genistein only partially decreased the activation of AP-1 under the same conditions.

\section{Discussion}

This study demonstrates that high glucose and Ang II stimulate PAI-1 gene expression in human VSMC, consistent with previous in vitro studies $[10,11]$ and clinical data $[4,7,25-28]$. As PAI-1 is considered to be a major inhibitor of plasminogen activation, the increase of plasma PAI-1 concentrations in diabetes and hypertension has been postulated to contribute to the development of atherosclerosis $[4,7,25]$, although there has not been a prospective study proving the causal relation. In our study the effect of high glucose and Ang II on PAI-1 gene expression is additive. This finding could explain why coexistence of 


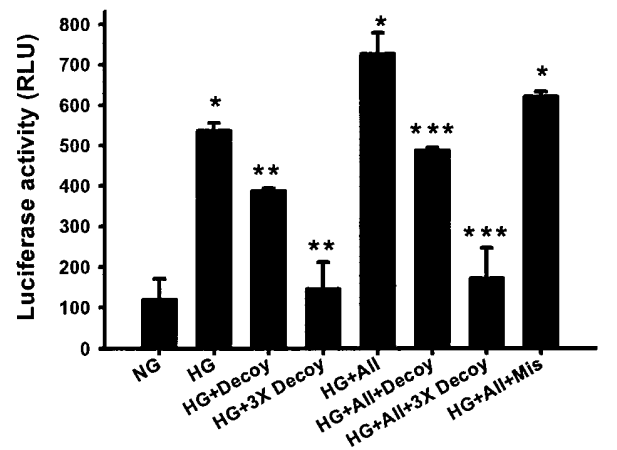

Fig. 6. Effect of $A P-1$ decoy ODN transfection on $P A I-1$ promoter activity (NG, VSMC cultured with normal glucose; HG, VSMC cultured with high glucose; Decoy, VSMC transfected with $100 \mathrm{nmol} / 1$ or $300 \mathrm{nmol} / 1(\times 3) A P-1$ decoy ODN; MIS, VSMC transfected with a mismatched decoy ODN). The lysates were examined for $\beta$-galactosidase activity and luciferase activity. Values are means \pm SEM of six independent experiments after normalization of $\beta$-galactosidase activity. $* p<0.01$ compared to $\mathrm{NG}, * * p<0.01$ compared to $\mathrm{HG}$, and $* * * p<0.01$ compared to $\mathrm{HG}+$ Ang II

hypertension and diabetes accelerates atherogenesis. Future studies are needed to clarify these clinical implications, including the effect of high glucose and Ang II on PAI-1 production in other cells, especially vascular endothelial cells or macrophages, as well as on production of t-PA, which is the most important physiological activator of fibrinolysis.

The concentration of Ang II used in our in vitro system was considerably higher than the normal circulating concentrations of Ang II in humans. Plasma concentrations of Ang II measured by radioimmunoassay and high-performance liquid chromatography were reported to be $6.6 \pm 0.5$ and $5.2 \pm 2.8$ (range $0.4-52.2) \mathrm{pmol} / \mathrm{l}$ respectively $[29,30]$. However, little is known about the local concentration of Ang II within the vascular tissues. Since the local concentrations of Ang II might be higher than circulating concentrations due to its autocrine-paracrine production [31], we selected the concentration to maximally induce $P A I-1$ mRNA expression.

It has been hypothesized that an increase in intracellular oxidative stress plays a key role in causing the endothelial dysfunction associated with hypertension and diabetes [32]. According to this hypothesis, various risk factors for atherosclerosis, including hypertension and diabetes, result in the generation of intracellular oxidative stress. AP-1 is one of the transcription factors influenced by the cellular redox state $[33,34]$. Activator protein 1 has been implicated in transcriptional regulation of a wide range of genes involved in cellular inflammatory responses, tissue destruction, and growth control. In VSMC, oxidative LDL, $\mathrm{H}_{2} \mathrm{O}_{2}$, and the lipid peroxidation product 4-hydroxy-2-nonenal have been shown to increase AP-1 expression or DNA binding activity [35-37]. In our study, transfection of an $A P-1$ decoy ODN, but not a
A)
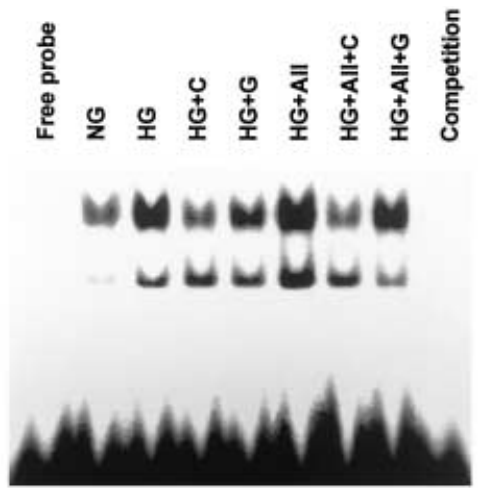

B)

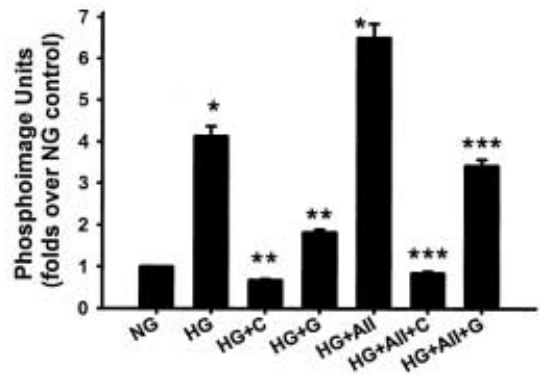

Fig. 7 A, B. Effect of PKC and tyrosine kinase inhibitor on AP-1 activity. A Typical example of a gel shift assay from VSMC treated with a PKC and a tyrosine kinase inhibitor. This experiment was repeated three times (NG, VSMC cultured with normal glucose; HG, VSMC cultured with high glucose; + C, VSMC treated with a specific PKC inhibitor, calphostin C (100 nmol/l); + G, VSMC treated with a tyrosine kinase inhibitor, genistein $(1 \mu \mathrm{mol} / \mathrm{l})$; + AII, VSMC treated with 100 nmol/l Ang II; Competition, cold $A P-1$ probe). B Quantification of EMSA results expressed as the means \pm SEM of three independent experiments. $* p<0.01$ compared to $\mathrm{NG}$, $* * p<0.01$ compared to $\mathrm{HG}$, and $* * * p<0.01$ compared to $\mathrm{HG}+$ Ang II

mismatched decoy ODN, effectively inhibited PAI-1 mRNA expression and protein secretion. Co-transfection of the $A P-1$ decoy ODN with the PAI-1 promoter construct also completely abolished luciferase expression. Thus, our data clearly show that AP-1 induced by high glucose or Ang II regulates PAI-1 gene expression and production.

We used a new decoy ODN approach to evaluate the influence of the AP-1 complex on PAI-1 gene expression. In general, reporter genes such as the chloramphenicol acetyl transferase (CAT) expression vector system have been used to study the roles of transcription factors $[18,38-40]$. This system is quite useful, but it might not reflect the endogenous gene regulation. On the other hand, the transfection of cis-element decoy ODNs used in our study provides a powerful new tool to study transcriptional regulation. Transfection of a decoy ODN corresponding to the AP-1 binding site sequence results in the attenua- 
tion of the authentic cis-trans interaction, leading to the removal of trans-factors from the endogenous cis-element, with the subsequent modulation of gene expression. It should be noted, however, that nonspecific effects of decoy ODNs can arise because several independent downstream genes can be regulated by the same transcription factor.

Our study provides information about the signal transduction system between ligands and AP-1 activation. Several previous studies have shown that high glucose-induced or Ang II-induced activation of AP-1 is dependent on PKC and/or tyrosine kinase $[41,42]$. We also show that AP-1 activation by either high glucose or Ang II is mediated mainly by PKC activation and partially by tyrosine kinase. Other signals, however, could also be involved in modulating AP-1 activity, and further studies are necessary to identify the cross-talk among these signals.

In conclusion, this study shows that high glucose and Ang II stimulate PAI-1 gene expression and protein production through AP-1 binding sites. Inhibition of AP-1 activity using a transcription factor decoy ODN effectively decreased the gene expression and production of PAI-1. These findings could contribute to a better understanding of the pathogenesis of cardiovascular disease.

Acknowledgements. This study was supported by a grant from the Institute for Medical Genetics, Keimyung University School of Medicine (97-1) and by a grant from the Korea Health 21 R\&D project, Ministry of Health \& Welfare, Republic of Korea (HMP-99-M-08-0004).

\section{References}

1. Krolewski AS, Warram JH, Valsania P, Martin BC, Laffel LMB, Christlieb AR (1991) Evolving natural history of coronary artery disease in diabetes mellitus. Am J Med 90 [Suppl 2A]: 56S-61S

2. Uusitupa MIJ, Niskanen LK, Siitonen O, Voutilainen E, Pyorala (1990) 5-year incidence of atherosclerotic vascular disease in relation to general risk factors, insulin level, and abnormalities in lipoprotein composition in non-insulin-dependent diabetic and nondiabetic subjects. Circulation 82 : 327-361

3. Brown MJ, Castaigne A, de Leeuw PW et al. (2000) Influence of diabetes and type of hypertension on response to antihypertensive treatment. Hypertension 35: 1038-1042

4. Schneiderman J, Sawdey MS, Keeton MR et al. (1992) Increased type 1 plasminogen activator inhibitor gene expression in atherosclerotic human arteries. Proc Natl Acad Sci USA 89: 6998-7002

5. Poli KA, Tofler GH, Larson MG et al. (2000) Association of blood pressure with fibrinolytic potential in the Framingham offspring population. Circulation 101: 264-269

6. Tomiyama H, Kimura Y, Mitsuhashi H et al. (1998) Relationship between endothelial function and fibrinolysis in early hypertension. Hypertension 31: 321-327

7. Schneiderman J, Loskutoff DJ (1991) Plasminogen activator inhibitors. Trends Cardiovasc Med 1: 99-102
8. Nordt TK, Klassen KJ, Schneider DJ, Sobel BE (1993) Augmentation of synthesis of plasminogen activator inhibitor type- 1 in arterial endothelial cells by glucose and its implications for local fibrinolysis. Arterioscler Thromb 13: $1822-1828$

9. Callicchio M, Argyriou S, Ianches G et al. (1994) Stimulation of PAI-1 expression in endothelial cells by cultured vascular smooth muscle cells. Arterioscler Thromb 14: 815-823

10. Feener EP, Northrup JM, Aiello LP, King GL (1995) Angiotensin II induces plasminogen activator inhibitor-1 and -2 expression in vascular endothelial and smooth muscle cells. J Clin Invest 95: 1353-1362

11. Feener EP, Xia P, Inoguchi T, Shiba T, Kunisaki M, King GL (1996) Role of protein kinase C in glucose- and Angiotensine II-induced plasminogen activator inhibitor expression. Contrib Nephrol 118: 180-187

12. Natarajan R, Scott S, Bai W, Yerneni KKV, Nadler J (1999) Angiotensin II signaling in vascular smooth muscle cells under high glucose conditions. Hypertension 33: 378-384

13. Wilmer WA, Cosio FG (1998) DNA binding of activator protein-1 is increased in human mesangial cells cultured in high glucose concentrations. Kidney Int 53: 1172-1181

14. Kudoh S, Komuro I, Mizuno T et al. (1997) Angiotensin II stimulates c-Jun NH2-terminal kinase in cultured cardiac myocytes of neonatal rats. Circ Res 80: 139-146

15. Karin M (1995) The regulation of AP-1 activity by mitogen-activated protein kinases. J Biol Chem 270: 16483-16486

16. Whitmarch AJ, Davis RJ (1996) Transcription factor AP-1 regulation by mitogen-activated protein kinase signal transduction pathway. J Mol Med 74: 589-607

17. Chen YQ, Su M, Walia RR, Hao Q, Covington JW, Vaughan DE (1998) Sp1 sites mediate activation of the plasminogen activator inhibitor-1 promoter by glucose in vascular smooth muscle cells. J Biol Chem 273: 8225-8231

18. Keeton MR, Curriden SA, Zonneveld AJ, Loskutoff DJ (1991) Identification of regulatory sequences in the type 1 plasminogen activator inhibitor gene responsive to transforming growth factor $\beta . \mathrm{J}$ Biol Chem 266: 23048-23052

19. Bielinska A, Shivdasani RA, Zhang L, Nabel GJ (1990) Regulation of gene expression with double-stranded phosphorothioate oligonucleotides. Science 250: 997-1000

20. Morishita R, Gibbons GH, Horiuchi M, Kaneda Y, Ogihara T, Dzau VJ (1998) Role of AP-1 complex in angiotensin II-mediated transforming growth factor- $\beta$ expression and growth of smooth muscle cells: Using decoy approach against AP-1 binding site. Biochem Biophys Res Commun 243: $361-367$

21. Sawa Y, Morishita R, Suzuki K et al. (1997) A novel strategy for myocardial protection using in vivo transfection of cis element 'decoy' against NF $\mathrm{B}$ binding site. Circulation 96: $280-285$

22. Ausubel FM, Brent R, Kingston RE et al. (1989) Current protocols in molecular biology. Greene Publishing Associates and Wiley-Interscience, New York

23. Saeki Y, Matsumoto N, Nakano Y, Mori M, Awai K, Kaneda Y (1997) Development and characterization of cationic liposomes conjugated with HVJ (Sendai virus): Reciprocal effect of cationic lipid for in vitro and in vivo gene transfer. Hum Gene Ther 8: 2133-2141

24. Abe M, Harpel JG, Metz CN, Nunes I, Loskutoff DJ, Rifkin DB (1994) An assay for transforming growth factor- $\beta$ using cells transfected with a plasminogen activator inhibitor-1 promoter-luciferase construct. Anal Biochem 216: 276-284 
25. Juhan-Vague I, Alessi MC, Vague P (1991) Increased plasma plasminogen activator inhibitor-1 levels. A possible link between insulin resistance and atherothrombosis. Diabetologia 34: 457-462

26. Pahor M, Pasty BM, Alderman MH, Applegate WB, Williamson JD, Furbeg CD (2000) Therapeutic benefits of ACE inhibitors and other antihypertensive drugs in patients with type 2 diabetes. Diabetes Care 23: 888-892

27. Powell JS, Clozel JP, Muller RKM et al. (1989) Inhibitors of angiotensin converting enzyme prevent myointimal proliferation after vascular injury. Science 245: 186-188

28. Hoogwerf BJ, Young JB (2000) The HOPE study. Ramipril lowered cardiovascular risk, but vitamin E did not. Cleve Clin J Med 67: 287-293

29. Hermann K, Ganten D, Unger T, Bayer C, Lang RE (1988) Measurement and characterization of angiotensin peptides in plasma. Clin Chem 34: 1046-1051

30. Simon D, Romestand B, Huang H et al. (1992) Direct simplified and sensitive assay of angiotensin II in plasma extracts performed with a high-affinity monoclonal antibody. Clin Chem 38: 1963-1967

31. Schunkert H, Ingelfinger JR, Hirsh AT et al. (1992) Evidence for tissue-specific activation of renal angiotensinogen mRNA expression in chronic stable experimental heart failure. J Clin Invest 90: 1523-1529

32. Kunsch C, Medford RM (1999) Oxidative stress as a regulator of gene expression in the vasculature. Circulation Res 85: 753-766

33. Winyard PG, Blake ER (1997) Antioxidant, redox-regulated transcription factors, and inflammation. Adv Pharmacol 38: 403-421

34. Sun Y, Oberley LW (1996) Redox regulation of transcriptional activators. Free Radic Biol Med 21: 335-348
35. Ares MP, Kallin B, Eriksson P. et al. (1995) Oxidized LDL induces transcription factor activator protein-1 butinhibits activation of nuclear factor-KB in human vascular smooth muscle cells. Arterioscler Thromb Vasc Biol 15: 1584-1590

36. Rao GN, Berk BC (1992) Active oxygen species stimulate vascular smooth muscle cell growth and proto-oncogene expression. Circ Res 70: 593-599

37. Ruef J, Rao GN, Li F et al. (1998) Induction of rat aortic smooth muscle cell growth by the lipid peroxidation product 4-hydroxy-2-nonenal. Circulation 97: 1071-1078

38. Arts J, Grimbergen J, Bosma PJ, Rahmsdorf HJ, Kooistra T (1996) Role of c-Jun and proximal phorbol 12-myristate-13-acetate-(PMA)-responsive elements in the regulation of basal and PMA-stimulated plasminogen-activator inhibitor-1 gene expression in HEPG2. Eur $\mathrm{J}$ Biochem 241: 393-402

39. Westerhausen DR, Hopkins WE, Billadello JJ (1991) Multiple transforming growth factor- $\beta$-inducible elements regulate expression of the plasminogen activator inhibitor type-1 gene in HepG2 cells. J Biol Chem 266: 1092-1100

40. Knudsen H, Olesen T, Riccio A, Ungaro P, Christensen L, Andreasen PA (1994) A common response element mediates differential effects of phorbol esters and forskolin on type-1 plasminogen activator inhibitor gene expression in human breast cancarcinoma cells. Eur J Biochem 220: 63-74

41. Wilmer WA, Cosio FG (1998) DNA binding of activator protein-1 is increased in human mesangial cells cultured in high glucose concentrations. Kidney Int 53: 1172-1181

42. Tamura K, Nyui N, Tamura N. et al. (1998) Mechanism of angiotension II-mediated regulation of fibronectin gene in rat vascular smooth muscle cell. J Biol Chem 273: 26487-26496 